\title{
Analytical characterization of some synthetic cannabinoids, derivatives of indole-3-carboxylic acid
}

\author{
Vadim Shevyrin $^{\mathrm{a}}$, Vladimir Melkozerov ${ }^{\mathrm{b}}$, Alexander Nevero ${ }^{\mathrm{c}}$, \\ Oleg Eltsov ${ }^{\mathrm{a}}$, Yuri Shafran ${ }^{\mathrm{a}, \mathrm{d}, *}$ \\ ${ }^{a}$ Ural Federal University, Institute of Chemistry and Technology, 19 Mira Str., 620002 Ekaterinburg, Russian Federation \\ ${ }^{\mathrm{b}}$ Expert and Criminalistic Center, Main Agency of the Ministry of the Interior of the Russian Federation, Sverdlovsk Region Branch, 17 Lenina Avenue, 620014 \\ Ekaterinburg, Russian Federation \\ c State Committee of Forensic Expertises of Republic of Belarus, 43 Kalvariyskaya Str., 220073 Minsk, Belarus \\ ${ }^{\mathrm{d}}$ TOSLab. Ltd., Bldg. 1, 5 Initsiativnaia Str., 121357 Moscow, Russian Federation
}

\section{A R T I C L E I N F O}

\section{Article history:}

Received 29 April 2013

Received in revised form 12 June 2013

Accepted 15 June 2013

Available online 17 July 2013

\section{Keywords:}

Derivatives of indole-3-carboxylic acid GC-HRMS

UHPLC-HRMS

MS/MS

NMR

FT-IR

Synthetic cannabinoids

\begin{abstract}
A B S T R A C T
By means of gas chromatography with high resolution mass spectrometry (GC-HRMS), ultra-high performance liquid chromatography in combination with high resolution tandem mass spectrometry (UHPLC-HRMS), nuclear magnetic resonance spectroscopy (NMR) and Fourier transform infrared spectroscopy (FT-IR), structure of a series from a novel synthetic cannabinoids, derivatives of indole-3carboxylic acid, was established. Methods for determination of the compounds in mixtures, involving chromatographic separation with mass-spectroscopic determination, were elaborated. Analytical data obtained in the paper will make reliable identification of synthetic cannabinoids of the new type during forensic examination possible.
\end{abstract}

(c) 2013 Elsevier Ireland Ltd. All rights reserved.

\section{Introduction}

In illegal market of psychoactive compounds, synthetic cannabinoids [1-23] became world-wide spread. To get round legislative prohibition of known compounds, drug dealers offer for consumption compounds with similar (modified) structure. That is why efficient determination of the structure of new psychoactive compounds occurring in illegal turnover becomes the most acute challenge, for forensic experts.

Beginning in October 2012, new type of synthetic cannabinoids, a structural modification of compounds from 3-naphthoylindole series [3-17] has begun to be seized by police regularly, on the territory of Russia and Belarus.

\footnotetext{
* Corresponding author at: Ural Federal University, Institute of Chemistry and Technology, 19 Mira Street, 620002 Ekaterinburg, Russian Federation. Tel.: +7 343375 4135; fax: +7 3433754135 .

E-mail addresses: vadim.shevyrin@gmail.com (V. Shevyrin), experts@ru66.ru (V. Melkozerov), a.s.nevero@gmail.com (A. Nevero),oleg-eltsov@yandex.ru (O. Eltsov),yu.m.shafran@ustu.ru, yuri.shafran@toslab.com (Yu. Shafran).
}

Most important - both in the sense of chemical classification and in juridical aspect - is that structural changes have effected carbonyl group in position 3 of indole ring resulting in new type of compounds, amides and esters of indole-3-carboxylic acid. Structures, chemical names and authors' conventional names for compounds under discussion are given in Table 1. For compounds 3-5, short names used by Internet-dealers are also given (in brackets).

Changing of keto group in position 3 of indole ring for amide one with the aim of preparation of new types of synthetic cannabinoids, was used already e.g. for the synthesis of narcotics in 3adamantoylindole and 3-adamantoylindazole series [19,20]. Moreover for compound 1, method of synthesis and biological activity were described in the literature [24], which made its emergence in illegal market of synthetic cannabinoids quite predictable. However identification of compound $\mathbf{1}$ - when is arose as a subject of expertise - was complicated by the absence of its analytical characteristics (except for ${ }^{1} \mathrm{H}$ NMR spectrum), in scientific literature. On contrary though compound $\mathbf{2}$ was not described, in the literature, it was an example of typical modification of compound $\mathbf{1}$. 
Table 1

Structures and chemical names of compounds 1-5.

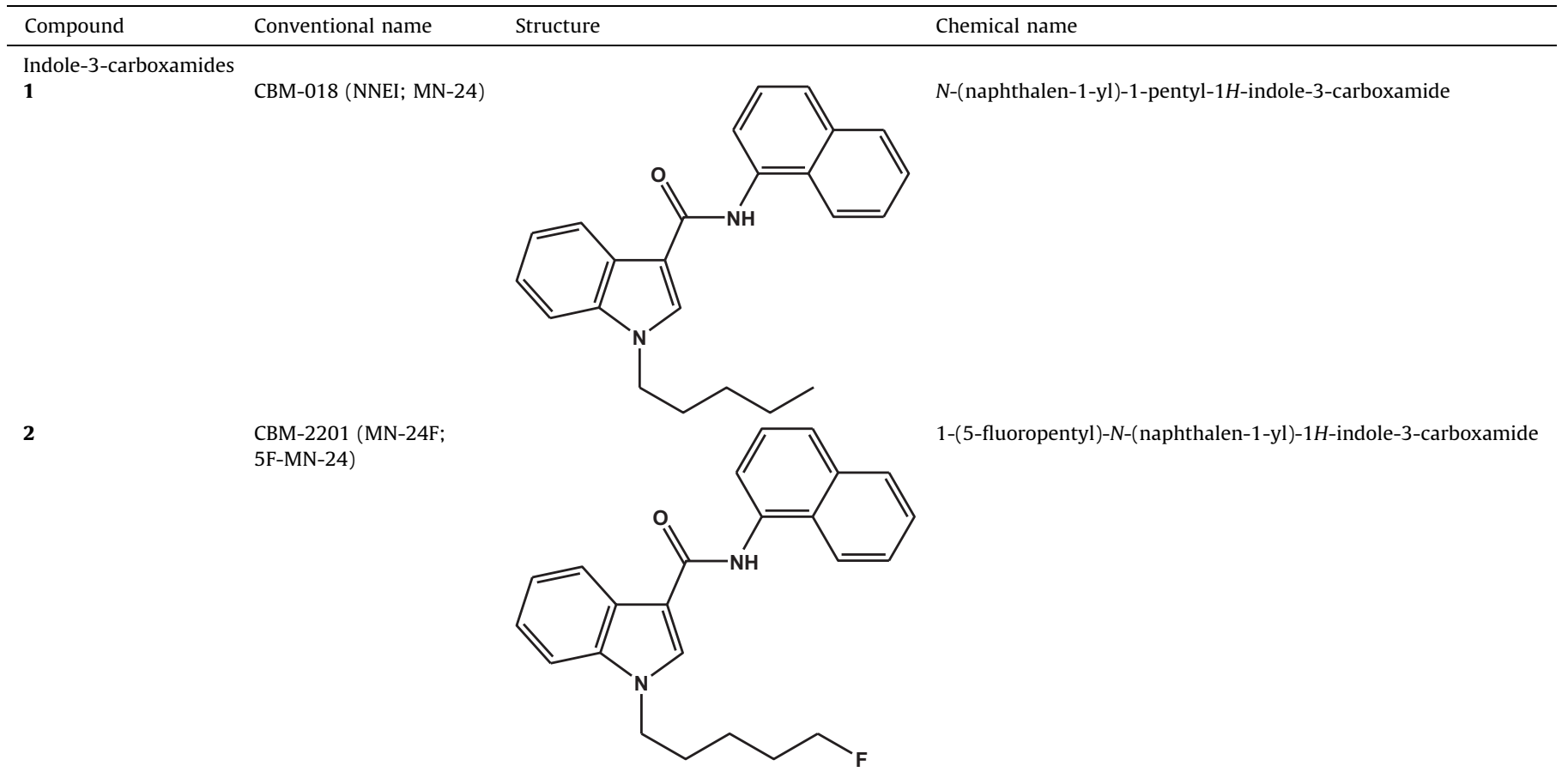

Indol-3-carboxylates 3

4

5
QCBL-018 (PB-22; MN-25; LTI-696; QUPIC)

QCBL-2201 (PB-22F; 5F-PB-22; MN-25F)

QCBL-CHM (BB-22; QUCHIC)<smiles>CCCCCn1cc(C(=O)Oc2cccc3cccnc23)c2ccccc21</smiles>

quinolin-8-yl 1-pentyl-1H-indole-3-carboxylate

quinolin-8-yl 1-(5-fluoropentyl)-1H-indole-3-carboxylate<smiles>O=C(Oc1cccc2cccnc12)c1cn(CCCCCF)c2ccccc12</smiles>

quinolin-8-yl 1-(cyclohexylmethyl)-1H-indole-3-carboxylate<smiles>O=C(Oc1cccc2cccnc12)c1cn(CC2CCCCC2)c2ccccc12</smiles> 
As for 8-oxiquinoline esters of $N(1)$-alkylindole-3-carboxylic acids (3-5), they are a result of absolutely new type of structural modification, and no data on their synthesis or biological activity could be found, in the literature. Some analytical characteristics of compounds $\mathbf{3}$ and $\mathbf{5}$ were published in the paper [25] recently.

It is worth noting that in compounds 1-5 only substituents in position 3 of indole were changed (in comparison with 3naphthoylindoles), while $N$-alkyl substituents were quite traditional for forbidden synthetic cannabinoids.

We have detected compounds $\mathbf{1 - 5}$ in numerous real evidences brought for examination to the forensic laboratories of Ekaterinburg (Russian Federation) and Minsk (Belarus) both in form of powders and in ready for use herbal mixtures.

In the course of elaboration of methods for sample preparation, we have noticed that the use of water-containing solvents e.g. 96\% ethanol lead to detection, during GC-HRMS analyses of compounds 3-5, a peak of 8-hydroxyquinoline. Its intensity was the higher the longer the solution was kept at room temperature before being analyzed. Most probably that was a result of partial hydrolysis of ester moiety in the presence of water. We assume that similar process takes place in vivo conditions as well. On contrary (as expected) there was no evidence of hydrolysis of amides $\mathbf{1}$ and $\mathbf{2}$ in the course of sample preparation.

In current paper, we report on determination of abovementioned compounds basing on analytical properties i.e. data of electron ionization (EI) and electrospray ionization (ESI) massspectra (including MS and MS/MS high resolution spectra), NMR spectroscopy and FT-IR spectra as well as on generalized log-linear retention indices $(\mathrm{GI})$ and retention times (RT) obtained in chromatographic conditions applied. These would help forensic experts to determine composition of seized psychoactive compounds.

\section{Materials and methods}

\subsection{Materials}

Subject substances were sampled in gram amounts from criminal evidences brought for examination. The samples for analysis were microcrystal white or pale beige powders, soluble in alcohols, acetone, chloroform and acetonitrile, and hardly soluble in water. Original crude samples containing compounds $\mathbf{1}$ and $\mathbf{2}$ had slight odor of naphthylamine.

Preliminary control by GC-HRMS and UHPLC-HRMS has revealed unidentified impurities in all samples. Therefore for NMR investigations and before recording FTIR spectra, compounds 1-5 were additionally purified by re-crystallization from ethyl acetate until no more contaminants were detected.

\subsection{Solvents and reagents}

Methanol ('for liquid chromatography' grade) was purchased from Merck KGaA (Darmstadt, Germany), water ('for GC, HPLC and Spectrophotometry' grade) from Honeywell Burdick and Jackson (Muskegon, USA), acetonitrile ('HPLCgradient' grade) - from Panreac (Barcelona, Spain), formic acid (98.0\% min.) - from Sigma-Aldrich (Steinheim, Germany), ethyl acetate ('analytical grade') - from Komponent-Reaktiv (Moscow, Russia). For recording NMR spectra, DMSO- $\mathrm{d}_{6}$ with isotopic purity $99.8 \% \mathrm{~min}$ ('A' grade, by TU 95-1893-89, St. Petersburg, Russia) was used. For determination of chromatography GI, a set of individual $n$-alkanes (Fluka, Sigma-Aldrich, Steinheim, Germany) was applied as a standard. For recording FT-IR spectra, potassium bromide (IR grade, Panreac, Barcelona, Spain) was used.

\subsection{Preparation of sample solution}

For qualitative analyses, ca. $1 \mathrm{mg}$ (for GC-MS) or ca. $0.5 \mathrm{mg}$ (for GC-HRMS) of each product was dissolved in $1 \mathrm{ml}$ methanol. After dissolving, solution was passed through a cellulose membrane filter (5064-8222, Agilent Technologies, USA) to serve as sample solution for analysis. For UHPLC-HRMS, the solution thus obtained was diluted with additional methanol to attain $5 \mu \mathrm{g} / \mathrm{ml}$. For all analyses, the solution was diluted with methanol to a suitable concentration before instrumental analysis if necessary.

\subsection{Instruments and Methods}

GC-MS Analysis of compounds in their solutions in methanol was performed with 'Agilent 7820A' gas chromatograph equipped with 'Agilent 5975' quadrupole mass selective detector and with GC-HRMS 'Agilent 7890A' connected with tandem quadrupole time-of-flight (QTOF) accurate mass detector 'Agilent 7200 Accurate-Mass Q-TOF GC/MS' (all - from Agilent Technologies, USA). The conditions were: capillary column HP-5ms with chemically immobilized (5\%biphenyl)-95\%-dimethylpolysiloxane (30.0 Ym $\times 0.25 \mathrm{~mm} \times 0.25 \mu \mathrm{m}, 19091 \mathrm{YS}$ 433. Agilent Technologies, USA), injector temperature was $280^{\circ} \mathrm{C}$, the transfer line temperature was maintained at $290^{\circ} \mathrm{C}$, MSD was operated in the EI mode $(70 \mathrm{eV})$, a mass range of total ion current of 30-550 yamu, TOF detector in extended dynamic range mode (EDR, $2 \mathrm{GHz}$ ) with acquisition rate 5 spectra/sec. Calibration of detectors and additional tuning of TOF detector before analysis was performed using perfluorotributylamine standard (PFTBA, 99.8\%, Agilent Technologies, USA). The oven temperature program used consisted of an initial temperature of $100{ }^{\circ} \mathrm{C}$; held for $2.0 \mathrm{~min}$; followed by a ramp to $290{ }^{\circ} \mathrm{C}$ with $20^{\circ} \mathrm{C} / \mathrm{min}$. The final temperature was held for $25 \mathrm{~min}$. Total run time was $36.5 \mathrm{~min}$.

The GC was operated in split mode (1:50 for GC-MS and 1:150 for GC-HRMS) with sample volume $1 \mu \mathrm{l}$ and with a helium as a carrier gas at flow rate $1.0 \mathrm{ml} / \mathrm{min}$ (constant flow).

UHPLC-HRMS was used with QTOF accurate mass detector 'Agilent 6540 UHD Accurate-Mass Q-TOF LC/MS' (Agilent Technologies, USA). Chromatographic separation was performed using a 'Agilent 1290 Infinity' ultra-high performance liquid chromatography system at $50{ }^{\circ} \mathrm{C}$ with an Zorbax Extend-C18 RRHT, $2.1 \times 50 \mathrm{~mm}, 1.8 \mu \mathrm{m}$, column (727700-902, Agilent Technologies, USA). For gradient elution, the mobile phases $0.1 \%$ formic acid in water $(A)$ and $0.1 \%$ formic acid in acetonitrile $(B)$ were used with the time program: 0 min $10 \% \mathrm{~B}$, linear to $15 \%$ B at $1 \mathrm{~min}$, linear to $100 \%$ B at $19 \mathrm{~min}$, constant $100 \%$ B to $20 \mathrm{~min}$, back to $10 \%$ $B$ and equilibration for $2 \mathrm{~min}$. The flow rate was $0.5 \mathrm{ml} / \mathrm{min}$. The spectra were measured by flow injection of $5 \mathrm{Yng}$ of each substance $(1 \mu \mathrm{l}$ of $5 \mu \mathrm{g} / \mathrm{ml}$ solution in methanol).

QTOF detector was used with electrospray ion source (DualESI) in positive ion mode. Nitrogen at $350^{\circ} \mathrm{C}$ with flow rate $10 \mathrm{l} / \mathrm{min}$ was used as a drying gas; nebulizer pressure $40 \mathrm{Ypsi}$. Capillary voltage $3500 \mathrm{~V}$, skimmer voltage $65 \mathrm{~V}$, fragmentor voltage $100 \mathrm{~V}$. In MS mode, quadrupole was adjusted for total ion current, but in MS/MS mode quadrupole was adjusted to isolate precursor ions only with isolation width $\Delta m / z=1.3$. MS/MS spectra were obtained using collision-induced dissociation (CID) of precursor ions with collision energies 10 and $20 \mathrm{eV}$ in hexapole collision cell with nitrogen as collision gas. MS spectra were registered within mass range 100-1700 Yamu and MS/MS spectra - within 50500 Yamu. TOF detector was operated in EDR $(2 \mathrm{GHz})$ mode, acquisition rate 1 spectra/sec. Spectra were internally mass corrected in real time using an automatically introduced reference mass solution containing two compounds: purine $\left([\mathrm{M}+\mathrm{H}]^{+}=121.050873\right)$ and HP-921 - hexakis $(1 \mathrm{H}, 1 \mathrm{H}, 3 \mathrm{H}$-tetrafluoropropoxy) phosphazine $\left([\mathrm{M}+\mathrm{H}]^{+}=922.009798\right)$.

${ }^{1} \mathrm{H}$ and ${ }^{13} \mathrm{C}$ NMR spectra were recorded on Bruker 'Avance II' spectrometer (Bruker, Switzerland) in DMSO-d 6 (400 and $100 \mathrm{MHz}$, respectively) using TMS as an internal standard. ${ }^{13} \mathrm{C}$ NMR spectra were recorded in $J$-mode (APT). Final assignment of the spectra was made by two-dimensional experiments ${ }^{1} \mathrm{H}-{ }^{13} \mathrm{C}$ Heteronuclear Multiple Bond Correlation (HMBC) and Heteronuclear Single Quantum Correlation (HMQC)

FT-IR spectra were recorded in KBr matrix by means of 'Avatar 370' (Nicolet, USA) Fourier transform IR (FT-IR) spectrometer in range $4000-400 \mathrm{~cm}^{-1}$, with resolution $4 \mathrm{~cm}^{-1}$, number of scans 16 - for the sample and 64 - for background.

\section{Results and discussions}

\subsection{Gas chromatography with MS detection}

EI HRMS for compounds 1-5 as well as their RT and GI [26] are given in Fig. 1.

It is worth to note that EI HRMS registered with TOF detector are rather similar to low resolution EI MS obtained with the use of quadrupole detector. The spectra are similar not only in the set of ions but also in their relative intensity. To estimate the similarity, low resolution spectra for compounds 1-5 were converted by means of 'NIST MS Program' and imported into the user MS library. Comparison of HRMS and the library MS spectra gave Match- and R.Match-factors in the range 900-920.

Analysis of MS spectra for compounds 1-5 shows that their fragmentation is similar to that for synthetic cannabinoids of 3phenylacetylindole series such as JWH-250 or JWH-203 $[6,9,12,23]$. This could lead (basing only on automatic search within libraries of MS - without visual control by an expert) to 

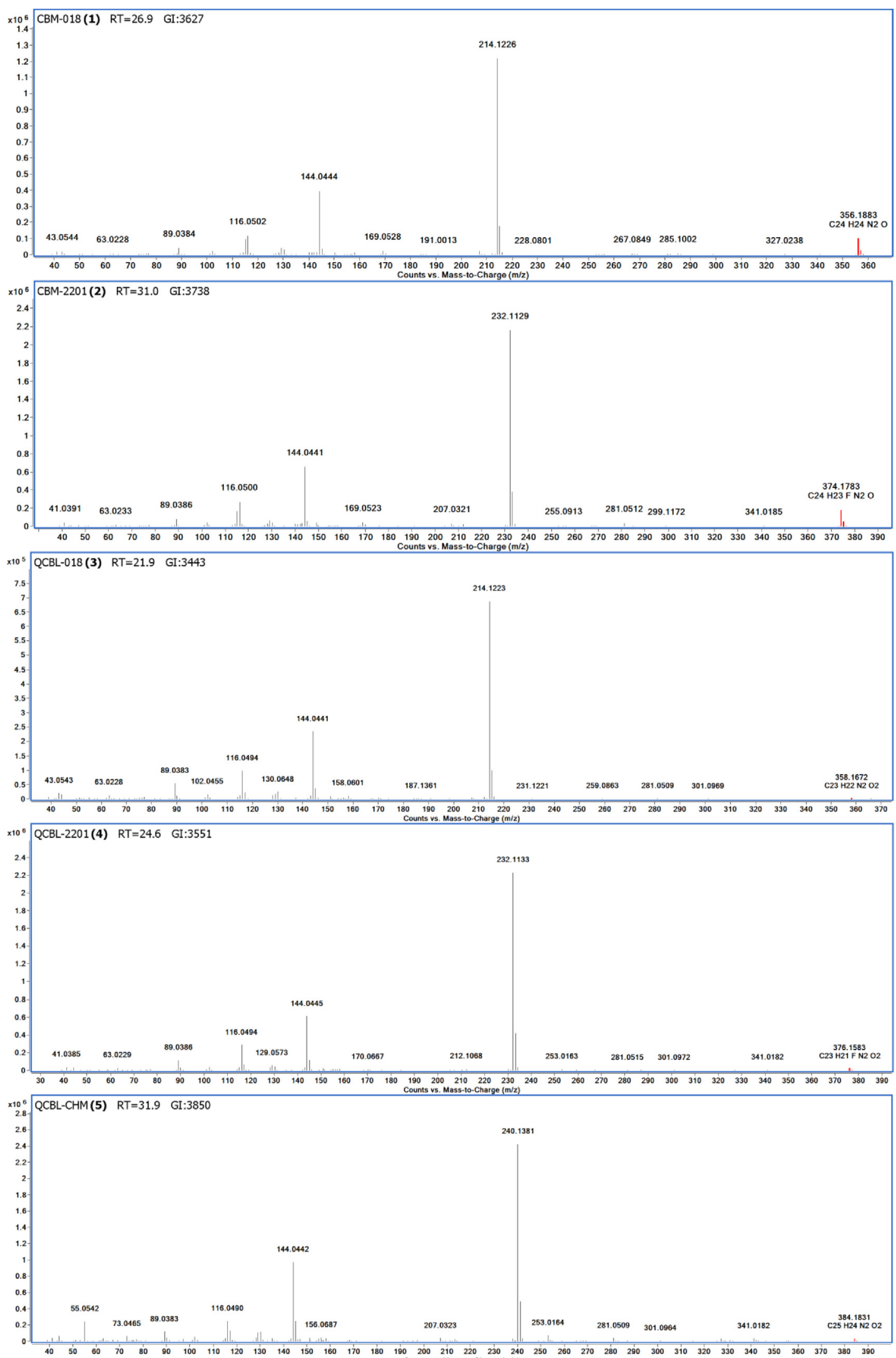

Fig. 1. EI HRMS, RT and GI for compounds 1-5 
Table 2

UHPLC-HRMS data for compounds 1-5.

\begin{tabular}{|c|c|c|c|c|c|}
\hline Compound & $\mathrm{RT}(\mathrm{min})$ & Molecular formula & Accurate mass (amu) & Exact mass (amu) & $\Delta m(\mathrm{ppm})$ \\
\hline 1 & 10.50 & $\mathrm{C}_{24} \mathrm{H}_{24} \mathrm{~N}_{2} \mathrm{O}$ & 356.1888 & 356.1889 & 0.07 \\
\hline 2 & 9.14 & $\mathrm{C}_{24} \mathrm{H}_{23} \mathrm{FN}_{2} \mathrm{O}$ & 374.1795 & 374.1794 & -0.20 \\
\hline 3 & 10.48 & $\mathrm{C}_{23} \mathrm{H}_{22} \mathrm{~N}_{2} \mathrm{O}_{2}$ & 358.1678 & 358.1681 & 0.86 \\
\hline 4 & 8.91 & $\mathrm{C}_{23} \mathrm{H}_{21} \mathrm{FN}_{2} \mathrm{O}_{2}$ & 376.1588 & 376.1587 & -0.19 \\
\hline 5 & 11.35 & $\mathrm{C}_{25} \mathrm{H}_{24} \mathrm{~N}_{2} \mathrm{O}_{2}$ & 384.1835 & 384.1838 & 0.79 \\
\hline
\end{tabular}

Table 3

HRMS/MS for compounds 1-5 in CID, ESI conditions.

\begin{tabular}{|c|c|c|}
\hline Compound & Collision energy $(\mathrm{eV})$ & $m / z$ (relative intensity) \\
\hline 1 & 20 & $\begin{array}{l}357,1956 \rightarrow 214,1223(100) ; 144,0440(3) ; 188,1428(2) ; 116,0494(<1) ; 132,0807(<1) ; 215,1262(<1) \\
118,0648(<1) ; 158,0605(<1) ; 89,0385(<1) ; 71,0856(<1)\end{array}$ \\
\hline 2 & 20 & $\begin{array}{l}375,1862 \rightarrow 232,1131(100) ; 144,0439(3) ; 206,1338(2) ; 116,0498(<1) ; 233,1158(<1) ; 118,0651(<1) \\
89,0391(<1) ; 69,0696(<1) ; 132,0807(<1) ; 212,1061(<1)\end{array}$ \\
\hline 3 & 10 & $\begin{array}{l}359,1752 \rightarrow 144,0443(1) ; 116,0502(<1) ; 215,1254(<1) ; 158,0566(<1) ; 214,6753(<1) ; 274,0530(<1) \\
301,1385(<1) ; 89,0383(<1) ; 298,1276(<1)\end{array}$ \\
\hline 4 & 10 & $\begin{array}{l}377,1656 \rightarrow 232,1128(100) ; 144,0439(1) ; 116,0494(<1) ; 233,1169(<1) ; 89,0387(<1) ; 69,0691(<1) \\
61,0435(<1) ; 212,1078(<1) ; 155,0706(<1) ; 130,0644(<1)\end{array}$ \\
\hline 5 & 10 & $\begin{array}{l}385,1903 \rightarrow 240,1377(100) ; 144,0440(1) ; 55,0546(<1) ; 241,1403(<1) ; 97,1012(<1) ; 116,0501(<1) \\
69,0704(<1) ; 89,0379(<1) ; 74,0971(<1) ; 63,0223(<1)\end{array}$ \\
\hline
\end{tabular}

erroneous attributing compounds of new class to cannabinoids of 3-phenylacetylindole series.

Thus main direction of fragmentation of compounds $\mathbf{1 - 5}$ is $\alpha$ cleavage which is typical for 3-acylindoles leading to formation of corresponding $\mathrm{N}$-alkylindolylacylium ions. Subsequent elimination of olefine from $N$-alkyl substituents and lose of $\mathrm{C}=\mathrm{O}$ lead to ions with $m / z 144.0444\left(\mathrm{C}_{9} \mathrm{H}_{6} \mathrm{NO}^{+}\right)$and $116.0495\left(\mathrm{C}_{8} \mathrm{H}_{6} \mathrm{~N}^{+}\right)$ which are characteristic for fragmentation of 3-acylindole compounds. At the same time fragment ions corresponding to substituents at carbonyl group are either not detected or could hardly be deduced because of possible masking due to overlapping with the other peaks. In this connection, analytical importance of molecular ions becomes higher. Moreover, for pairs 1 and 3, 2 and 4 values of molecular ions are the only distinguishing parameter.

\subsection{Ultra-high performance liquid chromatography mass- spectroscopy detection}

UHPLC-HRMS with QTOF detection enabled us to get additional data for identification of compounds 1-5 and to determine the nature of substituents in positions 1 and 3 of indole ring. When we used $100 \mathrm{eV}$ voltage on the ion source fragmentor, the only signals detected were those of protonated molecular ions, which made determination of accurate molecular masses of the compounds with minimal inaccuracy possible. Using software of MassHunter Qualitative Analysis B.05.00 instrument, these masses were calculated to give molecular formulae for compounds 1-5.

To study fragmentation of protonated molecules of compounds 1-5 induced by their collisions with neutral nitrogen molecules, we have carried out MS/MS experiments. The spectra thus obtained can serve stable analytical characteristic of compounds 1-5, which does not depend on ionization source condition and thus could be used for reliable identification of these compounds in seized samples.

Accurate and exact molecular masses, calculated molecular formulae as well as RT for compounds 1-5 are given in Table 2 . High resolution MS/MS spectral data in form of mass and relative intensity of ten most intensive peaks are shown in Table 3. HRMS/MS for compounds $\mathbf{1 - 5}$ as well as their RT are presented in Fig. 2.
In CID conditions, fragmentation of protonated molecules from compounds 1-5 basically involves cleavage of C-C-bonds and formation (as in EI) of corresponding indolylacylium ions (Fig. 3). Further fragmentation thereof leads to characteristic ions with lower $m / z$ value. Amide groups in compounds $\mathbf{1}$ and $\mathbf{5}$ make alternative direction of fragmentation (cleavage of bond between carbonyl function and indole ring) possible which leads to formation of corresponding alkyl- $1 \mathrm{H}$-indolium ions.

Cyclohexylmethyl substituent in compound $\mathbf{5}$ is proved not only with molecular formula, but also with ions $\mathrm{C}_{7} \mathrm{H}_{13}{ }^{+}(\mathrm{m} /$ $z=97.1012)$ and $\mathrm{C}_{4} \mathrm{H}_{7}{ }^{+}(m / z=55.0542)$ in its MS/MS.

\subsection{NMR spectroscopy ${ }^{1}$}

Chemical shifts and attributing of signals in NMR spectra for compounds 1-5 are shown in Tables 4 and 5. Final proof of structure for compounds 1-5 was made basing on their ${ }^{1} \mathrm{H}$ and ${ }^{13} \mathrm{C}$ NMR spectra using 2D experiments and data from reference literature [27]. Full NMR analysis including 2D experiments was performed only for two representative compounds, 1 (indole-3carboxamide) and $\mathbf{4}$ (indol-3-carboxylate). The assignment of signals in NMR spectra for compounds 2, 3 and $\mathbf{5}$ was made by analogy with compounds $\mathbf{1}$ and $\mathbf{4}$.

Integral intensity, chemical shifts and multiplicity of signals in ${ }^{1} \mathrm{H}$ NMR spectrum of compound 1 completely correspond to $\mathrm{N}$ (naphthalen-1-yl)-1-pentyl-1H-indole-3-carboxamide. In its ${ }^{13} \mathrm{C}$ NMR spectra recorded in $J$-mode (APT), number of oppositephase signals is also in accordance with the structure of compound 1.

In upfield part of proton spectrum for compound $\mathbf{1}$, signals of $\mathrm{H}-$ 1b, H-2b, H-3b, H-4b, H-5b which differ significantly in chemical shifts due to electron-withdrawing character of indole core are observed. This makes their unambiguous assessment possible. In downfield, singlets at 9.90 and $8.48 \mathrm{ppm}$ are characteristic for $\mathrm{NH}$ and $\mathrm{H}-2$ protons correspondingly. Multiplicity and spin-spin coupling constants for signals at $8.23,7.60,7.25$ and $7.18 \mathrm{ppm}$ are characteristic for protons $\mathrm{H}-4-\mathrm{H}-7$ from ortho-substituted

\footnotetext{
${ }^{1}$ NMR data were obtained in 'Laboratory of Complex Investigations and Expert Valuation of Organic Materials' of the Ural Federal University (Ekaterinburg, Russia).
} 

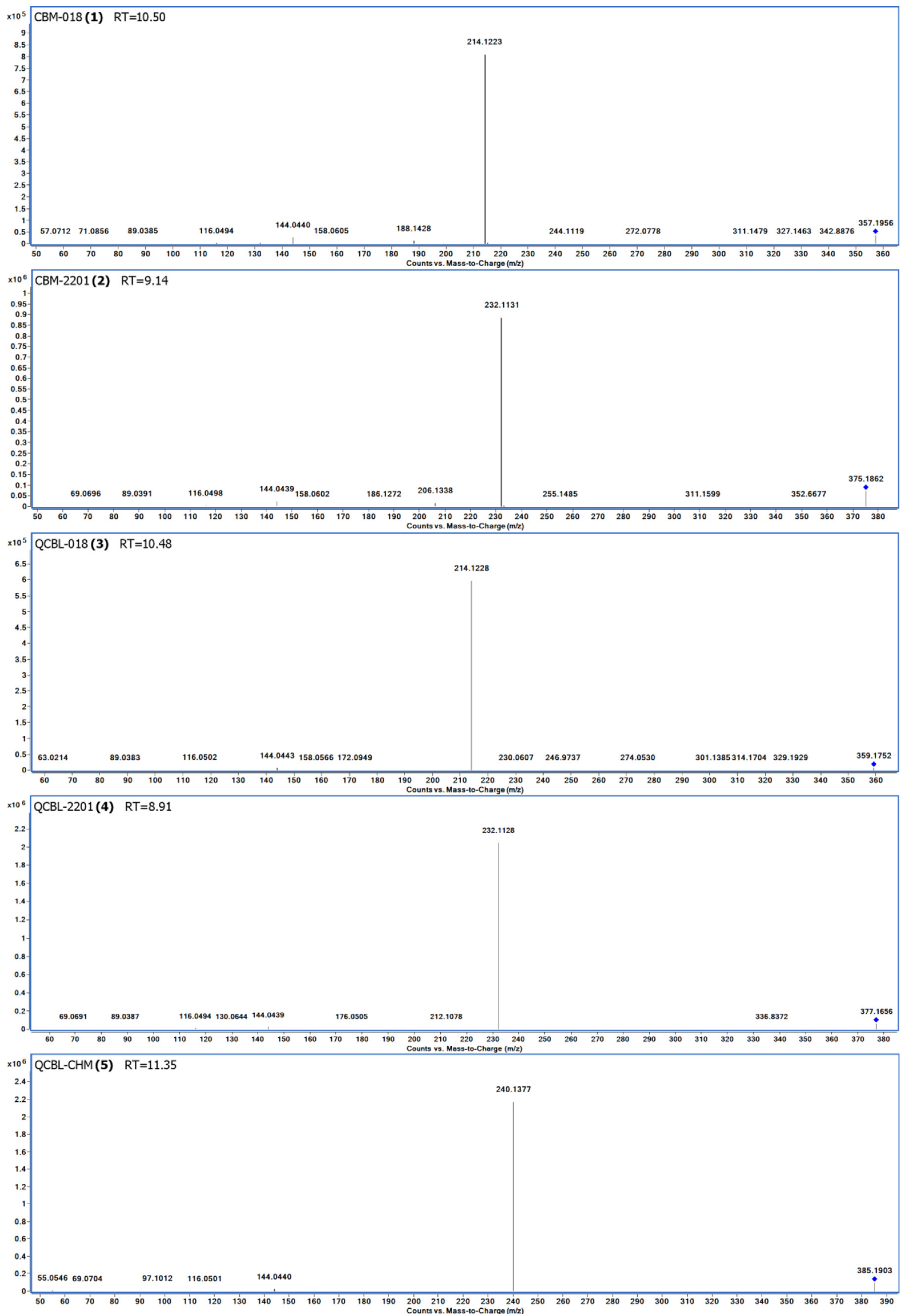

Fig. 2. HRMS/MS, RT for compounds $1-5$. 

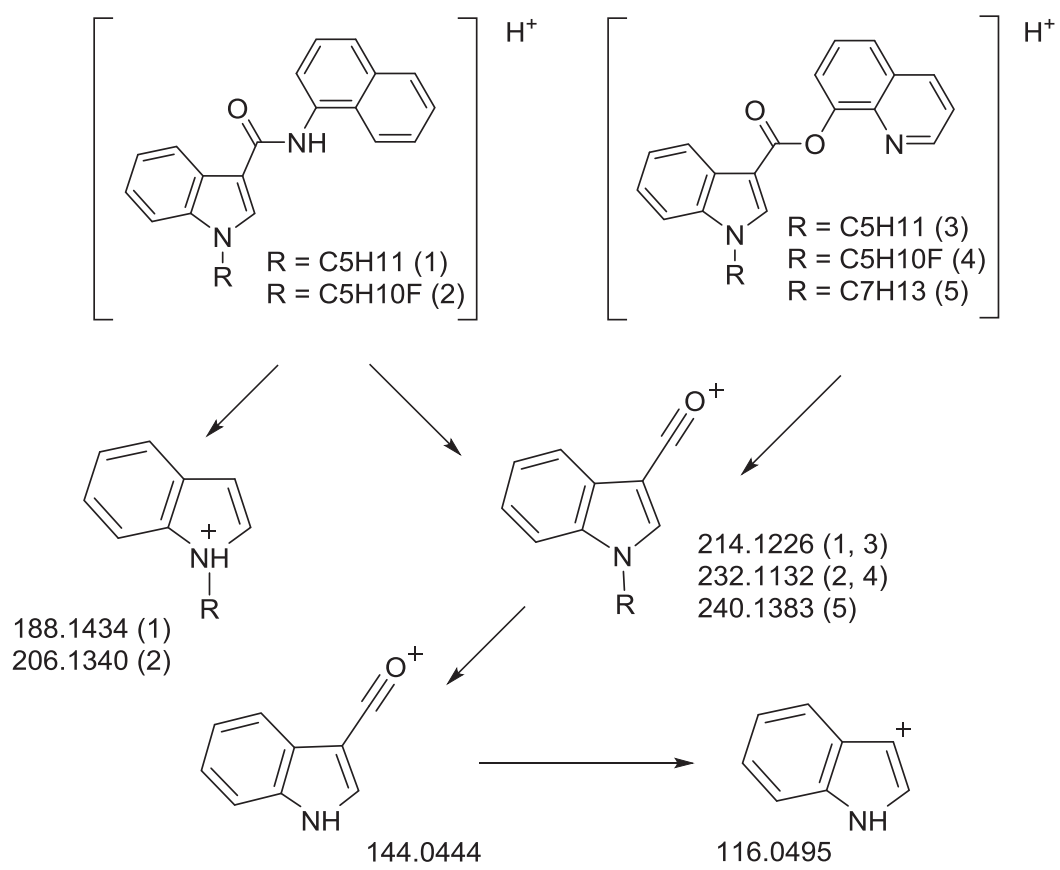

Fig. 3. Scheme of formation of main characteristic ions in MS/MS spectra for compounds 1-5.

Table 4

NMR spectra for compounds 1 and 2.

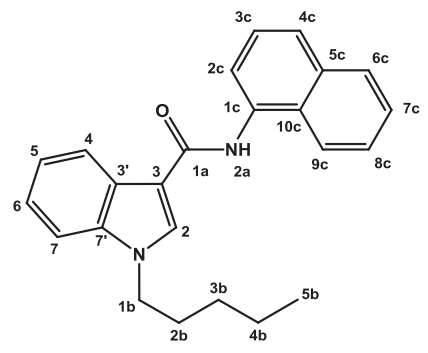

CBM-018 (1)

${ }^{1} \mathrm{H} \quad{ }^{13} \mathrm{C}$

8,48 (s., $1 \mathrm{H}$ )

$-$

8,23 (d., $1 \mathrm{H}, J=8.0 \mathrm{~Hz}$ )

7,18 (t., $1 \mathrm{H}, J=7.2 \mathrm{~Hz}$ )

7,25 (t., $1 \mathrm{H}, J=7.2 \mathrm{~Hz}$ )

7,60 (d., $1 \mathrm{H}, J=8.0 \mathrm{~Hz}$ ) overlapping

$-$

9.90 (s., 1H)

7.49-7.58 (m., 1H) overlapping

7.49-7.58 (m., 1H) overlapping

7.49-7.58 (m., 1H) overlapping

7.70 (d., $1 \mathrm{H}, J=7.2 \mathrm{YHz}$ )

7.93-8.00 (m., 1H)

8.07-8.14 (m., 1H)

7.81 (d., $1 \mathrm{H}, J=8.0 \mathrm{YHz}$ )

4.27 (t., $2 \mathrm{H}, J=7.2 \mathrm{YHz}$ )

1.86 (quin., $2 \mathrm{H}, J=7.2 \mathrm{YHz}$ )

1.26-1.42 (m., 2H) overlapping

1.26-1.42 (m., $2 \mathrm{H})$ overlapping 0.88 (t., $3 \mathrm{H}, J=7.2 \mathrm{YHz}$ )

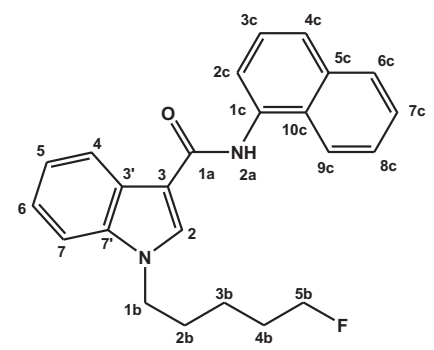

CBM-2201 (2)

${ }^{1} \mathbf{H}$

8.48 (s., $1 \mathrm{H})$

$-$

8.21 (d., $1 \mathrm{H}, J=8.0 \mathrm{~Hz})$

7.19 (t., $1 \mathrm{H}, J=7.2 \mathrm{~Hz})$

$7.26(\mathrm{t} ., 1 \mathrm{H}, J=7.2 \mathrm{~Hz})$

7.62 (d., $1 \mathrm{H}, J=8.0 \mathrm{~Hz}$ ) 110.5

163.6

9.91 (s., $1 \mathrm{H})$

134.2

7.52-7.59 (m., 1H) overlapping 125.6

7.52-7.59 (m., 1H) overlapping 125.6

7,52-7,59 (m., 1H) overlapping 125.9

7.70(d, 1H, J=7.2YHz) 133.8

7.70 (d., $1 \mathrm{H}, J=7.2 \mathrm{YHz})$

$7.93-8.00(\mathrm{~m} ., 1 \mathrm{H}) \quad 128.0$

$8.06-8.13(\mathrm{~m} ., 1 \mathrm{H})$

7.82 (d., $1 \mathrm{H}, J=8.0 \mathrm{YHz})$

$-\quad 129.0$

$4.31(\mathrm{t} ., 2 \mathrm{H}, J=7.2 \mathrm{YHz})$

1.91 (quin., $2 \mathrm{H}, J=7.6 \mathrm{YHz}$ ) 29.2

1.42 (quin., $2 \mathrm{H}, J=8.0 \mathrm{YHz}) \quad 22.1\left(\mathrm{~d} .,{ }^{3} J_{C-F}=5.1 \mathrm{YHz}\right)$

1.63-1.79 (d.m., 2H) 29.3 (d., ${ }^{2} J_{C-F}=19.1 \mathrm{YHz}$ )

4.51 and 4.39 (d.t., $\left.2 \mathrm{H},{ }^{2} J=6.0 /{ }^{3} J=47.6 \mathrm{YHz}\right) \quad 83.6$ (d., ${ }^{1} J_{C-F}=160.7 \mathrm{YHz}$ ) 
Table 5

NMR spectra for compounds 3-5.

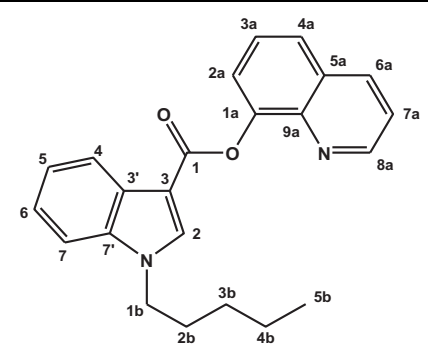

Number of $\mathrm{C}$ atom

\begin{tabular}{lll} 
& ${ }^{1} \mathrm{H}$ & ${ }^{13} \mathrm{C}$ \\
\hline 1 & - & 162.4 \\
2 & $8.49(\mathrm{s.}, 1 \mathrm{H})$ & 136.1 \\
3 & - & 104.5 \\
$3^{\prime}$ & - & 126.4 \\
4 & $8.07(\mathrm{~d} ., 1 \mathrm{H}, J=8.0 \mathrm{~Hz})$ & 120.7 \\
5 & $7.26(\mathrm{t} ., 1 \mathrm{H}, J=8.0 \mathrm{~Hz})$ & 122.0 \\
6 & $7.32(\mathrm{t} ., 1 \mathrm{H}, J=8.0 \mathrm{~Hz})$ & 122.6 \\
7 & $7.64-7.73(\mathrm{~m} ., 1 \mathrm{H})$ overlapping & 111.1
\end{tabular}

$7^{\prime}$

$1 \mathrm{a}$

$2 a$

$3 a$

$4 a$

$5 a$

$6 a$

$7 a$

$8 a$

$9 a$

$1 \mathrm{~b}$

$2 b$

$3 b$

$4 \mathrm{~b}$

$5 b$

$6 b$

7b

$-$

7.64-7.73 (m., 1H) overlapping

136.4
147.2

121.7

7.91-7.98 (m., 1H)

7.64-7.73 (m., 1H) overlapping

125.7

121.9

8.46 (d.d., $1 \mathrm{H},{ }^{3} \mathrm{~J}=8.0 \mathrm{~Hz} /{ }^{4} \mathrm{~J}=1.6 \mathrm{~Hz}$ )

129.1

7.59 (d.d., $1 \mathrm{H},{ }^{3} \mathrm{~J}=8.0 \mathrm{~Hz} / 4.3 \mathrm{~Hz}$ )

8.86 (d.d., $1 \mathrm{H},{ }^{3} J=4.3 \mathrm{~Hz} /{ }^{4} \mathrm{~J}=1.6 \mathrm{~Hz}$ )

4.34 (t., $2 \mathrm{H}, J=7.2 \mathrm{~Hz}$ )

141.1

46.1

1.85 (quin., $2 \mathrm{H}, J=7.2 \mathrm{~Hz}$ )

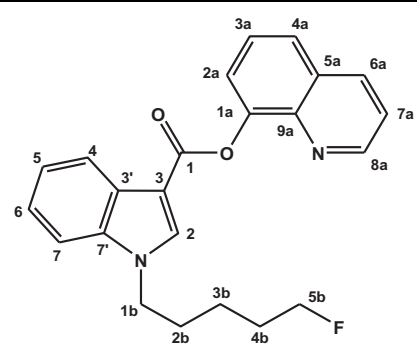

QCBL-2201 (4)

${ }^{1} \mathrm{H} \quad{ }^{13} \mathrm{C} \quad{ }^{1} \mathrm{H}$

- 162.3

8.50 (s., $1 \mathrm{H}) \quad 136.0$

- 104.5

126.4

8.07 (d., $1 \mathrm{H}, J=8.0 \mathrm{~Hz}) \quad 120.7$

7.26 (t., $1 \mathrm{H}, J=8.0 \mathrm{~Hz}) \quad 122.0$

$7.32(\mathrm{t} ., 1 \mathrm{H}, J=8.0 \mathrm{~Hz}) \quad 122.6$

7.64-7.73 (m., 1H) $\quad 111.0$

overlapping

$-$

overlapping

7.91-7.98 (m., 1H) $\quad 125.7$

7.64-7.73 (m., 1H) 121.9

overlapping

129.0

8.45 (d.d., $1 \mathrm{H},{ }^{3} \mathrm{~J}=8.0 \mathrm{~Hz} / \quad 136.5$

$\left.{ }^{4} \mathrm{~J}=1.6 \mathrm{~Hz}\right)$

126.47 .58 (d.d., $1 \mathrm{H},{ }^{3} \mathrm{~J}=8.0 \mathrm{~Hz}$ /

$4.3 \mathrm{~Hz})$

$150.4 \quad 8.86$ (d.d., $1 \mathrm{H},{ }^{3} \mathrm{~J}=4.3 \mathrm{~Hz}$

${ }^{4} \mathrm{~J}=1.6 \mathrm{~Hz}$ )

4.31-4.43 (m., 2H)

overlapping

1.89 (quin., $2 \mathrm{H}, J=7.2 \mathrm{~Hz}$ )

1.39 (quin., $2 \mathrm{H}, J=8.0 \mathrm{~Hz}$ )

126.4

150.3

1.61-1.78 (d.m., 2H)

4.31-4.43 (m., 1H)

overlapping and 4.49

(t., $1 \mathrm{H},{ }^{2} J=6.0 \mathrm{~Hz}$ )
141.1

46.0

29.1

22.0

(d., ${ }^{3} J_{C-F}=5.2 \mathrm{~Hz}$ )

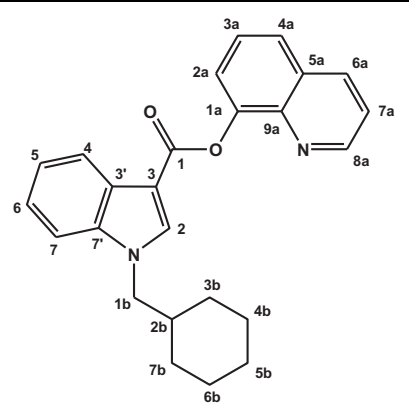

QCBL-CHM (5)

${ }^{1} \mathrm{H}$

8.42 (s., 1H)

$-$

8.06 (d., $1 \mathrm{H}, J=8.0 \mathrm{~Hz}$ )

7.25 (t., $1 \mathrm{H}, J=8.0 \mathrm{~Hz}$ )

7.31 (t., $1 \mathrm{H}, J=8.0 \mathrm{~Hz}$ )

7.64-7.72 (m., 1H)

overlapping

$-$

7.64-7.72 (m., 1H)

overlapping

7.91-7.97 (m., 1H)

7.64-7.72 (m., $1 \mathrm{H})$

overlapping

8.46 (d.d., $1 \mathrm{H},{ }^{3} \mathrm{~J}=8.0 \mathrm{~Hz}$ /

${ }^{4} \mathrm{~J}=1.6 \mathrm{~Hz}$ )

7.58 (d.d., $1 \mathrm{H},{ }^{3} \mathrm{~J}=8.0 \mathrm{~Hz}$ |

$4.3 \mathrm{~Hz})$

8.86 (d.d., $1 \mathrm{H},{ }^{3} \mathrm{~J}=4.3 \mathrm{~Hz}$ /

${ }^{4} J=1.6 \mathrm{~Hz}$ )

4.20 (d., $2 \mathrm{H}, J=7.2 \mathrm{~Hz}$ )

1.83-1.97 (m., 1H)

0.98-1.11 (m., $1 \mathrm{H})$ and

$1.52-1.65(\mathrm{~m} ., 1 \mathrm{H})$

overlapping

$29.3 \quad 1.11-1.25(\mathrm{~m} ., 1 \mathrm{H})$ and

(d., $\left.{ }^{2} J_{C-F}=19.2 \mathrm{~Hz}\right) \quad 1.65-1.75(\mathrm{~m} ., 1 \mathrm{H})$

overlapping

$83.5 \quad 1.11-1.25(\mathrm{~m} ., 1 \mathrm{H})$ and

(d., $\left.{ }^{1} J_{C-F}=160.8 \mathrm{~Hz}\right)$

$1.52-1.65(\mathrm{~m} ., 1 \mathrm{H})$

overlapping

$1.11-1.25(\mathrm{~m} ., 1 \mathrm{H})$ and

1.65-1.75 (m., 1H)

overlapping

$0.98-1.11(\mathrm{~m} ., 1 \mathrm{H})$ and

$1.52-1.65(\mathrm{~m} ., 1 \mathrm{H})$

overlapping benzene system. Signals at 8.07, 7.93, 7.81 and $7.55 \mathrm{ppm}$ could be assigned to protons $\mathrm{H}-2 \mathrm{c}-\mathrm{H}-4 \mathrm{c}$ and $\mathrm{H}-6 \mathrm{c}-\mathrm{H}-9 \mathrm{c}$ of naphthalene ring.

Cross-peaks between protons of $\alpha-\mathrm{CH}_{2}$ group of $\mathrm{N}$-1-substituent and $\mathrm{H}-2$ in $\mathrm{HMBC}$ spectrum $\left(\mathrm{H}-1 \mathrm{~b} / \mathrm{C}-7^{\prime}, \mathrm{H}-1 \mathrm{~b} / \mathrm{C}-2\right.$ and $\mathrm{H}-2 / \mathrm{C}-3^{\prime}$, $\left.\mathrm{H}-2 / \mathrm{C}-3, \mathrm{H}-2 / \mathrm{C}-1 \mathrm{a}, \mathrm{H}-2 / \mathrm{C}-1 \mathrm{~b}, \mathrm{H}-2 / \mathrm{C}-\mathrm{7}^{\prime}\right)$ play a key role in assessment of signals of protons and carbons of indole ring. Further HMBC analysis of cross-peaks between C-3', C-3 and C-7' carbons and protons brought us to unambiguous assessment of indole core protons. Signals of $\mathrm{CH}$-carbons of indole cycle were assigned basing on the data of HSQC spectrum.

We have found that $\mathrm{NH}-2 \mathrm{a}$-proton gives cross peaks not only with C-1a carbonyl carbon but with another three carbons, C-1c,
C-2c and C-10c as well. Analysis of cross-peaks between these carbons and naphthalene protons $\mathrm{H}-2 \mathrm{c}-\mathrm{H}-4 \mathrm{c}, \mathrm{H}-6 \mathrm{c}-\mathrm{H}-9 \mathrm{c}$ enabled us to assign signals of protons and carbons from naphthalene fragment.

Similar approach was used to assignment of signals in NMR spectra for compound 4. Thus integral intensity, chemical shifts and multiplicity of signals in ${ }^{1} \mathrm{H}$ NMR spectrum of compound 4 completely correspond to quinolin-8-yl 1-(5-fluoropentyl)- $1 \mathrm{H}$ indole-3-carboxylate. In its ${ }^{13} \mathrm{C}$ NMR spectra recorded in $\mathrm{J}$-mode (APT), number of opposite-phase signals is also in accordance with the structure of compound 4.

Pattern of signals of $\mathrm{H}-1 \mathrm{~b}, \mathrm{H}-2 \mathrm{~b}, \mathrm{H}-3 \mathrm{~b}, \mathrm{H}-4 \mathrm{~b}$ and $\mathrm{H}-5 \mathrm{~b}$ protons in upfield of ${ }^{1} \mathrm{H}$ NMR spectrum of compound $\mathbf{4}$ is complicated with 
their interaction with fluorine atom. In ${ }^{13} \mathrm{C}$ spectrum, signals of fluoroalkyl substituents are shifted downfield significantly due to electron-withdrawing character of fluorine and appear as doublets with characteristic spin-spin coupling constants $\left({ }^{1} J_{C-F}=160.8 \mathrm{~Hz}\right.$, ${ }^{2} J_{C-F}=19.2 \mathrm{~Hz},{ }^{3} J_{C-F}=5.2 \mathrm{~Hz}$ ).

In downfield part of proton spectrum for compound $\mathbf{4}$, singlet at $8.50 \mathrm{ppm}$ is characteristic for $\mathrm{H}-2$ proton. Multiplicity and spin-spin coupling constants for signals at 8.07, 7.32 and $7.26 \mathrm{ppm}$ are characteristic for protons $\mathrm{H}-4$ - H-6 from orthosubstituted benzene system. Signals at 8.86, 8.45, 7.94 and $7.58 \mathrm{ppm}$ could be assigned to protons of quinoline ring. Multiplet at 7.64-7.73 ppm is formed by overlapping of signals of protons from quinoline $(\mathrm{H}-2 \mathrm{a}$ and $\mathrm{H}-4 \mathrm{a})$ and indole cycles ( $\mathrm{H}-7)$.

Cross-peaks between protons of $\alpha-\mathrm{CH}_{2}$ group of $\mathrm{N}-1$ substituent and $\mathrm{H}-2$ in $\mathrm{HMBC}$ spectrum for compound 4 (H-1b/C-7', H-1b/C-2 and H-2/C-3', H-2/C-3, H-2/C-1a, H-2/C$1 \mathrm{~b}, \mathrm{H}-2 / \mathrm{C}-\mathrm{7}^{\prime}$ ) play a key role in assessment of signals of protons and carbons of indole ring. Further $\mathrm{HMBC}$ analysis of cross-peaks between $\mathrm{C}-3^{\prime}, \mathrm{C}-3$ and $\mathrm{C}-7^{\prime}$ carbons and protons brought us to unambiguous assessment of indole core protons. Signals of $\mathrm{CH}-$ carbons of indole cycle were assigned basing on the data of HSQC spectrum.
According to general concepts in NMR spectroscopy and in compliance with calculations by means of a packet of programs from ACDLabs, C-8a-proton should be most downfield - among the protons of quinoline cycle and was actually found as doublet of doublets at $8.86 \mathrm{ppm}$ (d.d., $1 \mathrm{H},{ }^{3} \mathrm{~J}=4.3 \mathrm{~Hz},{ }^{4} \mathrm{~J}=1.6 \mathrm{~Hz}$ ). Signals of carbon atom in bridge (C-9a) and in proton-bearing (C-7a and C6a) carbons were identified by characteristic cross-peaks between them and C-8a-proton. Consecutive analyses of cross-peaks between fixed carbons and the other protons in quinoline lead to total assignment of the rest of signals of quinoline protons and carbons.

\subsection{FT-IR spectroscopy}

FT-IR spectra for compounds $\mathbf{1 - 5}$ are shown in Figs. 4 and 5. Strong absorbance bands corresponding to valence vibrations of carbonyl group around $1635 \mathrm{~cm}^{-1}$ (for amides $\mathbf{1}$ and 2) or in the range $1716-1724 \mathrm{~cm}^{-1}$ (for esters 3-5) are characteristic for such compounds [27] and are in concordance with suggested structures. Intense bands of valence vibrations of C-O-bond at $1083-1086 \mathrm{~cm}^{-1}$ in FT-IR spectra for compounds 3-5 serve an additional evidence for ester function in their structure.

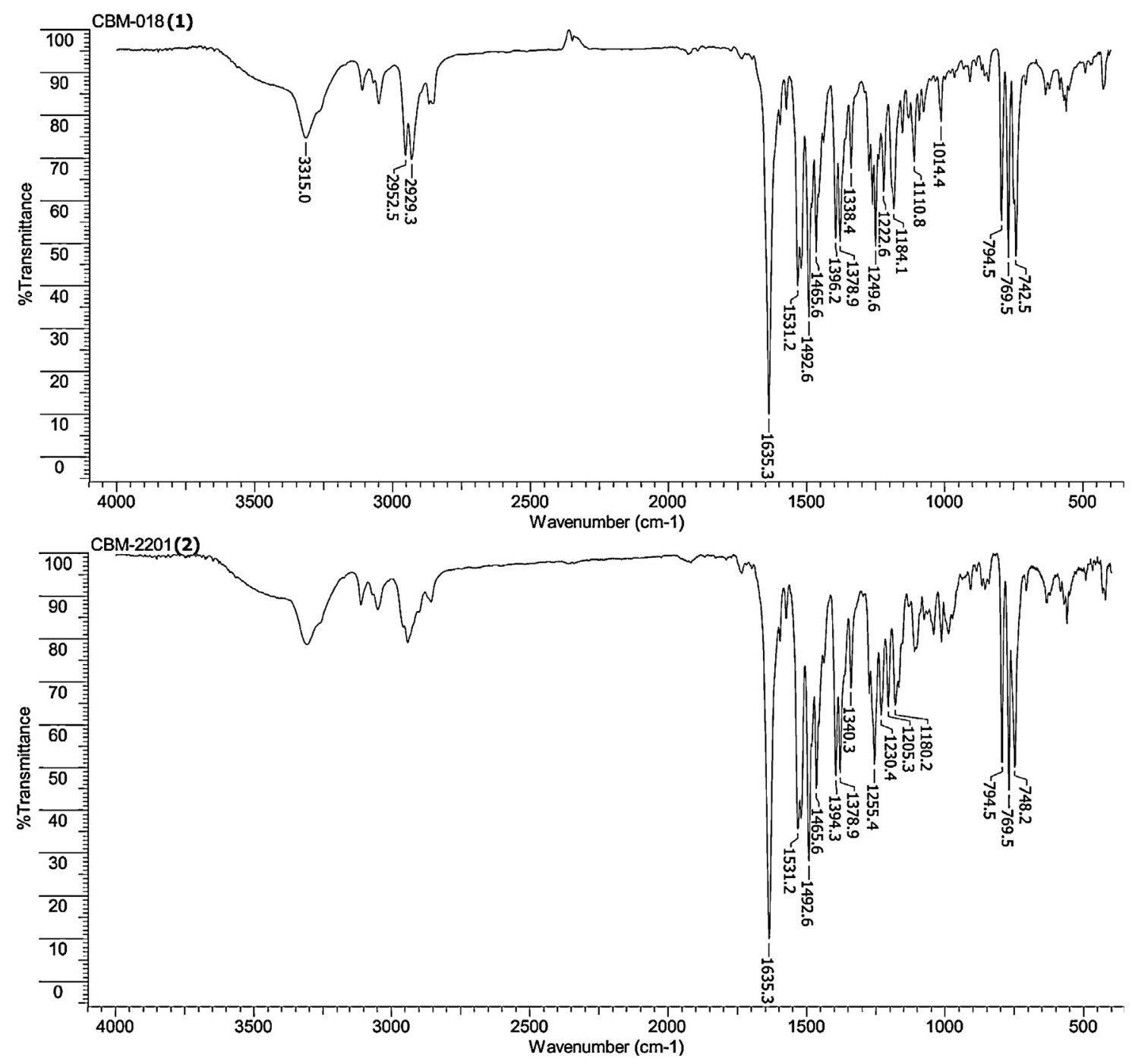

Fig. 4. FT-IR spectra for compounds 1, 2 . 


\section{Conclusion}

Derivatives of indol-3-carboxlic acid, a novel type of synthetic cannabinoids could be used as narcotics and are found in illegal turnover. In current study, the structure of a series of such compounds was determined. Analytical characteristics obtained for the compounds from this novel type of synthetic cannabinoids will make their reliable identification during forensic examination by means of chromatographic and mass-spectrometric methods possible.

\section{References}

[1] United Nation Office on Drugs and Crime (UNODC), Synthetic Cannabinoids in Herbal Products, 2013 URL: www.unodc.org/documents/scientific/Synthetic_Cannabinoids.pdf.

[2] A.C. Howlett, F. Barth, T.I. Bonner, G. Cabral, P. Casellas, W.A. Devane, C.C. Felder, M. Herkenham, K. Mackie, B.R. Martin, R. Mechoulam, R.G. Pertwee, International Union of Pharmacology. XXVII. Classification of cannabinoid receptors, Pharmacol. Rev. 54 (2) (2002) 161-202

[3] V. Auwarter, S. Dresen, W. Weinmann, M. Muller, M. Putz, N. Ferreiros, 'Spice' and other herbal blends: harmless incense or cannabinoid designer drugs? J. Mass Spectrom. 44 (2009) 832-837.

[4] R. Lindigkeit, A. Boehme, I. Eiserloh, M. Luebbecke, M. Wiggermann, L. Ernst, T. Beuerle, Spice:a never ending story? Forensic Sci. Int. 191 (2009) 58-63.

[5] N. Uchiyama, R. Kikura-Hanajiri, N. Kawahara, Y. Goda, Identification of a cannabimimetic indole as a designer drug in a herbal product, Forensic Toxicol. 27 (2009) 61-66.

[6] N. Uchiyama, M. Kawamura, R. Kikura-Hanajiri, Y. Goda, Identification and quantitation of two cannabimimetic phenylacetylindoles JWH-251 and JWH-250, and four cannabimimetic naphthoylindoles JWH-081, JWH-015, JWH-200, and JWH-073 as designer drugs in illegal products, Forensic Toxicol. 29 (2011) 25-37.

[7] N. Uchiyama, R. Kikura-Hanajiri, N. Kawahara, Y. Haishima, Y. Goda, Identification of a cannabinoid analog as a new type of designer drug in a herbal product, Chem. Pharm. Bull. 57 (2009) 439-441.

[8] J. Nakajima, M. Takahashi, T. Seto, C. Kanai, J. Suzuki, M. Yoshida, T. Hamano, Identification and quantitation of two benzoylindoles AM-694 and (4-methoxyphenyl)(1-pentyl-1H-indol-3-yl) methanone, and three cannabimimetic naphthoylindoles JWH-210, JWH-122, and JWH-019 as adulterants in illegal products obtained via the Internet, Forensic Toxicol. 29 (2011) 95-110.

[9] S. Kneisel, F. Westphal, P. Rosner, V. Brecht, A. Ewald, B. Klein, M. Putz, S. Thiemt, V. Auwarter, Cannabimimetics: mass spectra and IR-ATR spectra of new compounds from the years 2009 and 2010, TIAFT Bull. 41 (1) (2011) 38-48.

[10] S. Kneisel, F. Westphal, B. Moosmann, V. Brecht, P. Bisel, C. Vidal, A. JacobsenBauer, W.-R. Bork, V. Auwarter, Cannabimimetics II: mass spectra and ATR-IR spectra of new compounds between the end of 2010 and late 2011, TIAFT Bull. 41 (3) (2011) 29-38

[11] S. Kneisel, P. Bisel, V. Brecht, S. Broecker, M. Muller, V. Auwarter, Identification of the cannabimimetic AM-1220 and its azepane isomer (N-methylazepan-3-yl)-3(1-naphthoyl)indole in a research chemical and several herbal mixtures, Forensic Toxicol. 30 (2012) 126-134.

[12] N. Uchiyama, R. Kikura-Hanajiri, J. Ogata, Y. Goda, Chemical analysis of synthetic cannabinoids as designer drugs in herbal products, Forensic Sci. Int. 198 (2010) 31-38.
[13] S. Dresen, N. Ferreiros, M. Putz, F. Westphal, R. Zimmermann, V. Auwarter, Monitoring of herbal mixtures potentially containing synthetic cannabinoids as psychoactive compounds, J. Mass Spectrom. 45 (2010) 1186-1194.

[14] J. Nakajima, M. Takahashi, R. Nonaka, T. Seto, J. Suzuki, M. Yoshida, C. Kanai, T. Hamano, Identification and quantitation of a benzoylindole (2-methoxyphenyl)(1-pentyl-1H-indol-3-yl)methanone and a naphthoylindole 1-(5-fluoropentyl-1H-indol-3-yl)(naphthalene-1-yl)methanone (AM-2201) found in illegal products obtained via the Internet and their cannabimimetic effects evaluated by in vitro [35S]GTPyS binding assays, Forensic Toxicol. 29 (2011) 132-141.

[15] L. Ernst, H.-M. Schiebel, C. Theuring, R. Lindigkeit, T. Beuerle, Identification and characterization of JWH-122 used as new ingredient in "Spice-like" herbal incenses, Forensic Sci. Int. 208 (2011) e31-e35.

[16] F. Westphal, F.D. Sönnichsen, S. Thiemt, Identification of 1-butyl-3-(1-(4methyl)naphthoyl)indole in a herbal mixture, Forensic Sci. Int. 215 (2012) $8-13$.

[17] S. Hudson, J. Ramsey, The emergence and analysis of synthetic Cannabinoids, Drug Test. Anal. 3 (2011) 466-478

[18] P. Jankovics, A. Varadi, L. Tolgyesi, S. Lohner, J. Nemeth-Palotas, J. Balla, Detection and identification of the new potential synthetic cannabinoids 1-pentyl-3-(2 iodobenzoyl)indole and 1-pentyl-3-(1-adamantoyl)indole in seized bulk powders in Hungary, Forensic Sci. Int. 214 (2012) 27-32.

[19] N. Uchiyama, M. Kawamura, R. Kikura-Hanajiri, Y. Goda, Identification of two new-type synthetic cannabinoids, $\mathrm{N}$-(1-adamantyl)-1-pentyl- $1 \mathrm{H}$-indole-3-carboxamide (APICA) and N-(1-adamantyl)-1-pentyl-1H-indazole-3-carboxamide (APINACA), and detection of five synthetic cannabinoids, AM-1220, AM-2233, AM-1241, CB-13 (CRA-13), and AM-1248, as designer drugs in illegal products, Forensic Toxicol. 30 (2012) 114-125.

[20] V. Shevyrin, V. Melkozerov, Yu. Morzherin, Identification and analytical characteristics of two new-type synthetic cannabinoids of indazole, Butlerov Commun. 30 (4) (2012) 93-98 (in Russian).

[21] V. Shevyrin, V. Melkozerov, A. Nevero, O. Eltsov, Y. Morzherin, Y. Shafran, Identification and analytical properties of new synthetic cannabimimetics bearing 2, 2,3,3-tetramethyl cyclopropanecarbonyl moiety, Forensic Sci. Int. 226 (2013) 62-73.

[22] J. Nakajima, M. Takahashi, T. Seto, J. Suzuki, Identification and quantitation of cannabimimetic compound JWH-250 as an adulterant in products obtained via the Internet, Forensic Toxicol. 29 (2011) 51-55.

[23] M. Bononi, P. Belgi, F. Tateo, Analytical data for identification of the cannabimimetic phenylacetylindole JWH-203, J. Anal. Toxicol. 35 (2011) 360-363.

[24] A.R. Blaazer, J.H.M. Lange, M.A.W. van der Neut, A. Mulder, F.S. den Boon, T.R. Werkman, Ch.G. Kruse, W.J. Wadman, Novel indole and azaindole (pyrrolopyridine) cannabinoid (CB) receptor agonists: Design, synthesis, structure-activity relationships, physicochemical properties and biological activity, Eur, J. Med. Chem. 46 (2011) 5086-5098.

[25] N. Uchiyama, S. Matsuda, M. Kawamura, R. Kikura-Hanajiri, Y. Goda, Two newtype cannabimimetic quinolinyl carboxylates, QUPIC and QUCHIC, two new cannabimimetic carboxamide derivatives, ADB-FUBINACA and ADBICA, and five synthetic cannabinoids detected with a thiophene derivative $\alpha$-PVT and an opioid receptor agonist AH-7921 identified in illegal products, Forensic Toxicol. 31 (2013) 223-240. http://link.springer.com/article/10.1007\%2Fs11419-0130182-9.

[26] B.V. Stoliarov, I.M. Savinov, A.G. Vitenberg, L.A. Kartsova, I.G. Zenkevich, V.I. Kalmanovsky, Yu.A. Kalambet, Practical Gas and Liquid Chromatography, St. Petersburg University, St. Petersburg, 2002, pp. 249-252 (in Russian).

[27] E. Pretsch, P. Bühlmann, C. Affolter, Structure Determination of Organic Compounds: Tables of Spectral Data, Springer, Berlin, 2004. 